\title{
What is the matter with citizenship? A Turkish debate
}

\section{Ahmet Içduygu, Yilmaz Çolak \& Nalan Soyarik}

To cite this article: Ahmet Içduygu, Yilmaz Çolak \& Nalan Soyarik (1999) What is the matter with citizenship? A Turkish debate, Middle Eastern Studies, 35:4, 187-208, DOI: 10.1080/00263209908701291

To link to this article: https://doi.org/10.1080/00263209908701291

$$
\text { 曲 Published online: } 06 \text { Dec } 2006 .
$$

Submit your article to this journal $\lambda$

Џlll Article views: 482

Citing articles: 25 View citing articles $\square$




\title{
What is the Matter with Citizenship? A Turkish Debate
}

\author{
AHMET İÇDUYGU, YILMAZ ÇOLAK \\ and NALAN SOYARIK
}

Fundamental to the establishment of the Turkish Republic was the development of a new concept of citizenship in the national polity that would go hand in hand with the nation-building process. Mustafa Kemal, the founder of the Republic, perceived citizenship as the very core of the legitimacy of the Republic. ${ }^{1}$ Accordingly, he himself actively participated in designing a compulsory course of civic education that was to be taught in the schools of Turkey. In those early days of the Republic, civic education in the country began with the course entitled Malumat-l Vataniyye (Information about the Motherland) which was included in school curricula in 1924. In 1927, it was replaced by Yurt Bilgisi (again the same meaning, Information about the Motherland), and finally from 1985 on, it was offered with the title of Vatandaşlık Bilgileri (Information about Citizenship). ${ }^{2}$ In other words, from the very start in Turkey, citizenship was officially taken to be one of the key elements of successful nation-building.

Despite the fact that from the very beginning, citizenship had a deep underlying significance for the construction of the new Turkish society and state, social science literature seldom explicitly discussed the concept of citizenship in Turkey beyond its ideological implications regarding nationalist heritage. In addition to these implications, Turks often thought of their citizenship as serving goals and practices of a universal kind reflected in Western political and philosophical tradition: defining the rights, obligations and identity of individuals in the country, citizenship concerns the relations that individual members of the state have among each other and with the governing body. Now, however, this comfortable scenario is challenged on two fronts. At the present time, Turkey finds itself reacting to the naturalization policies and practices of migrant-receiving states, in which thousands of its emigrant citizens are in search of access to citizenship and citizenship rights in those states, and consequently 'dual citizenship' has become an issue of increasing concern. On the other hand, it has to deal with the question of how the free expression of ethnic 
(Kurdish), religious (Islamic) and sectarian (Alevi) revivalism is possible under the unitary principles of the Turkish state and citizenship, and accordingly 'constitutional citizenship' is repeatedly pronounced. In these circumstances Turkish citizens have been forced to ask whether they have a distinct 'citizenship' identity of their own which is challenged by the forces of migration, ethnicity, and religion challenge. The new citizenship debate in Turkey is essentially centred on these three forces.

The purpose of this article is to consider the extent to which issues of 'constitutional citizenship' and 'dual citizenship' are integral parts of the current citizenship debate in Turkey. Of course, one can claim that these two issues are so utterly dissimilar in nature that it is obviously ambitious to attempt to discuss them both in the same brief article. But we stress the need for an evaluation of these issues together as they come into play on the citizenship debate in Turkey today. To this end the essay explains some of the difficulties inherent in both the content of these two terms and their implications for the concept of citizenship itself. Next, an outline of approaches to citizenship from the beginning of the Republic to the present day is offered to provide perspective on the current debate concerning the level of citizenship practices that Turkish citizens enjoy. An indication of the extent of the citizenship debate in Turkey is drawn from the most recent public and scholarly discussions in the country. This latter issue is then explored in the light of recent developments in relevant social issues, such as international migration and ethnic and religious revivalism, and a discussion of the politics of mobility and ethnicity is opened up. A conclusion points the way to future directions in these areas.

The concept of citizenship has received renewed interest in the last ten years, since globalization has become a popular issue. This recent interest is as multifaceted as it is immense. Various political events and trends throughout the world are seen as being responsible for the increasing global importance of the concept of citizenship: for instance, the resurgence of nationalist movements in Eastern Europe; the stresses created by an increasingly multicultural and multiracial population in Western Europe; the refugee problem which has created a new crisis of stateless persons in the contemporary political system, and so forth. ${ }^{3}$ What all these developments imply is that the conventional concept of the nation-state has been profoundly challenged by global events and trends, and consequently, citizenship as an issue has become prominent.

Studies which link citizenship to the rise and stability of nation-states perceive the former as an outcome of modernity, and consider it as a transition from status to contract. ${ }^{4}$ Thus, in its simplest formulation, 
citizenship corresponds to the contract-like status of membership in a nation-state. But this membership has different aspects. For instance, Hammar delineates four interrelated meanings of citizenship; namely legal, political, social and cultural, and psychological. ${ }^{5}$ The legal dimension is formal membership in a state, based on specific rules and connotes a number of rights and duties. The political dimension specifies the position of the individual in the polity as citizen, and thus forms the basis of the state. In the cultural and social sense it signifies the membership of a nation. And finally, psychologically it provides an expression of individual identification. From Hammar's perspective, it is obvious that more than a legal status, citizenship is seen as an identity expressing an individual's membership in a definitive politico-cultural community.

Similarly, Brubaker's analysis, referring to an ideal-typical model, provides an analytical study of the membership status of citizenship. Brubaker, who also defines citizenship as membership of the nation-state, draws his argument from the contention that each nation-state attempts to have a certain population as its own which can be identified as something more than individuals in order that a cohesive and homogeneous nation can be constructed. By regarding the nation-state both as an idea and an ideal, Brubaker delineates six membership norms for the ideal-typical model. According to this model, this membership should be egalitarian, sacred, nation-based, democratic, unique, and consequential. ${ }^{6}$ The distinguishing feature of Brubaker's approach arises from the fact that he conducts a comparative analysis which attempts to elaborate the link between different conceptions of nationhood and citizenship by focusing on nation-state formations in France and Germany. More specifically, Brubaker bases the expansive conception of citizenship in the French context which he depicts as stemming from the principle of $j u s$ soli, on the contention that nationhood in the French vocabulary was state-centred and assimilationist. Distinguishing the German case as Volk-centred and differentialist, he finds the identifying features of German citizenship to be based on jus sanguinis. In this respect, Brubaker notes that by drawing upon a specific ethnocultural dimension, Germany failed to integrate the egalitarian, democratic, nationalist and statist aspects of citizenship which had been realized in France. Such a remark leads him to conclude that the evolution of citizenship in Germany displayed a diversified path among formal state membership, participatory citizenship and ethno-cultural nation membership. ${ }^{7}$ What is clear meanwhile is that both the French and German models of citizenship were deeply affected by the concept of 'nation', even though its meaning was different from one to another.

The relationship between the concept of citizenship, defined as the legally acknowledged membership of a state, and the concept of 
nationhood, defined as the socially acknowledged belonging to a nation, is the core context in which the various membership status of individuals and citizenship rights are questioned. Having defined state as a legal and political organization, with the power to require obedience and loyalty from its citizens, and nation as a community of people, whose members are bound together by a sense of solidarity, a common culture, a national consciousness, it is possible to argue that 'while state is a legal and political concept, nation is a cultural one'. ${ }^{8}$ With such a distinction made, it is also possible to argue that the notion of a homogeneous nation-state, which is based on the ideal of 'one nation in one state', is more a fiction than a reality. Working contrary to the theoretical construction of an ideal nationstate, emergence of the competing forms of national, regional, ethnic, or religious identities makes an important contribution to the increasing heterogeneity of populations in the nation-states. The implied assumption is that there are fundamental challenges to governance where the society appears increasingly fragmented into a multitude of groups, each having its own distinct identity and issuing social and political demands based on their identity. ${ }^{9}$

Considering the question of pluralism, the core issue of citizenship today is the cultural fragmentation in modern nation-states. Members of these states have different and competing cultural identities which often undermine the shared identity signified by their citizenship. As elaborated by Marshall, ${ }^{10}$ citizenship can be taken as a shared identity that would integrate previously ignored groups within the society and provide a source of unity. When Marshall gave an historical account of the development of citizenship in Britain through the evolution of civil, political and social elements, he indeed saw the citizenship as a tool not only to integrate the people to the common culture, but also to construct this 'common possession and heritage'. It has become clear, however, that many citizens with their distinct identities today have serious difficulties in becoming a part of the common culture in their nation-states, despite possessing the common rights of citizenship. ${ }^{11}$ In other words, the conventional notion of citizenship fails to deal with the "problems that are associated with equality in the context of difference'. ${ }^{2}$ Behind this failure, it is believed that there is the notion of universality which results in both an abstract notion of citizenindividual identity and a general notion of common citizenship identity. Both of these identities, citizen-individual identity and common citizenship identity, imply that all individuals are given the same formal and legal rights regardless of gender, race, ethnicity, religion or class. From this conventional perspective, citizenship is an issue of viewing people as individuals with equal rights under the law. Consequently, in our contemporary world, it is seen that neither of these notions of citizenship 
can take account of identity differences and accommodate the special unmet needs of distinct identity groups. The conventional notion of citizenship is unable to respond to the requirements of the principle of pluralism. Keyman puts the case with the following statement: '...the unitary conceptions of modern self (as a political class identity or a citizen identity or a national identity) can no longer play their unifying function; nor are they capable of dissolving difference into sameness'. ${ }^{13}$

What is required then is a new form of citizenship, a membership status in a modern democratic state which neither necessitates a homogeneous socio-political community nor subordinates various identity groups, but rather recognizes the diversity of identities, even values them, and incorporates them into the larger community, or common culture. It is within this context that an increasing number of scholars emphasize the need of modelling some new types of citizenship in our modern democracies. The models currently being debated include, among others, the concepts of multicultural citizenship, ${ }^{14}$ differentiated citizenship, ${ }^{15}$ constitutional citizenship ${ }^{16}$ and dual, ${ }^{17}$ or multiple, citizenship. Considering their relevance to our discussion of the Turkish case, two of these specific types of citizenship, multiple citizenship (generally known as dual citizenship) and constitutional citizenship, are elaborated here in some detail.

What is generally known as dual citizenship, or rarely as multiple citizenship, signifies that one person holds the membership, i.e. citizenship status, of more than one state, as a consequence of international migration. Given the importance of citizenship as a key to participation in a sociopolitical community, and as a symbol of commitment to the future of this community, international migration is a challenge to both the theory and the practice of governance in migrant-sending and migrant-receiving countries. Indeed, the status of millions of migrants around the world is often socially and politically anomalous. International migration leads to the emergence of large groups of foreign citizens who, for all intents and purposes, are permanent residents but cannot fully benefit from their citizenship rights. Although one can acknowledge the difficulties in coping with the diversity of established policies, practice and outlook with regard to immigration and admission to citizenship in various nation-states, the liberalization of naturalization and dual (multiple) citizenship rights seem to be practical solutions. ${ }^{18}$ The notion of dual, multiple, citizenship suggests that citizenship is formal legal membership of a state, implying loyalty to the state rather than the nation, and it is important for both symbolic and practical reasons with the emphasis on the latter. Of course, the content of dual citizenship within the boundaries of the 'theory of citizenship' is at the centre of a significant debate. Although the full details of this debate are not 
in the scope of our study, some aspects of the debate on dual, multiple citizenship will be elaborated in more detail by referring to the Turkish case.

Although the concept of constitutional identity, or constitutional citizenship, remains largely undefined, we might take it 'to refer to that aspect of our collective and individual self-conception which we owe to our shared constitutional heritage'. ${ }^{19}$ Constitutional citizenship, which often comes to the fore in relation to the possibility of a European identity transcending the identity of nation-states in the European Union ${ }^{20}$ implies a supra-national identity guaranteed by the constitution to function as a common identity denominator for the diversity and integrity of the different forms of life coexisting in a multicultural environment. The original idea of constitutional identity, constitutional citizenship, or constitutional patriotism suggests that democratic citizenship in our modern states does not need to be rooted in the national identity of a people. However, it does require that citizens, without divorcing themselves from their diversity of different cultural forms of life, should be socialized into a common political culture. If 'a constitution can be thought of as an historical project that each generation of citizens continues to pursue', ${ }^{21}$ then the concept of constitutional citizenship can be seen as a driving force for the dynamic project of creating a new common identity. This collective identity provides a socio-political setting for the manner in which a common politico-cultural self-understanding would emerge by differentiation from the cultural orientations of different national, ethnic, and religious identities. On the other hand, if the constitution expresses formal consensus among various identities ${ }^{22}$ the concept of constitutional citizenship would contribute to the question of how to deal with a diversity of identities so that identity and otherness would complement rather than exclude one another. Accordingly, on the basis of constitutional citizenship every person would 'receive equal protection and equal respect in their integrity as irreplaceable individuals, as members of ethnic or cultural groups, and as citizens, that is, as members of the political community'. ${ }^{23}$ It is believed that by recognizing and including the diversity and otherness in one common identity, constitutional identity would contribute to the integrative function of citizenship. It is also believed that the demand for both representational rights and multicultural rights coming from various identities is a demand for inclusion, not for exclusion..$^{2+}$

In order to understand and grasp the parameters and nature of the official concept of citizenship in Turkey (in the development of which the state played the determinant role), this section will attempt to portray the process by which it was constructed. The development of Republican citizenship is 
divided into three basic time periods: first, the Single Party period (1923-50); second, the period from 1950 to 1980; and third, the 1980 military intervention and its aftermath.

The laws and regulations aiming at institutionalizing the status of citizenship in the Turkish Republic had close links with Ottoman modernization. Attempts at modernization in the Ottoman Empire gained impetus by the proclamation of Gülhane Hatt-l Hümayunu, which initiated a reformation period called Tanzimat. Tanzimat was based on the secularization of religious laws and implementation of new administrative, educational and financial policies for reorganizing the state structure in conformity with European models. For the first time in Ottoman history a legislative act was put into practice, dependent on the principle of securing the life, honour and property of all subjects regardless of their religion. It also brought about limitations on the Sultan's power to the advantage of the bureaucracy. ${ }^{25}$ By the Tanzimat reform movement and the 1876 constitution, generally speaking, the subjects living in the Empire were taken as individuals making a society, not simply as the being parts of different religious-ethnic communities. ${ }^{26}$ The first legal regulation on the issues of Ottoman citizenship was dated 23 January 1869 Tabiiyet-i Osmaniyeye dair Nizamname. ${ }^{27}$ The Regulation was based on descent, only those born to Ottoman parents were regarded as Ottoman citizens; however, territorial understanding was exercized in a limited manner for those born in the territory of the Empire after they reached maturity.

The first attempt to search for a Turkish identity for the citizens of the Empire in light of the modern nationalist ideals appeared with the government of the Committee of Union and Progress, from 1908 to 1918. The Young Turks introduced a new understanding that 'the nation was the source of all authority', ${ }^{28}$ and so they made the first attempt to transform the Empire into a model of a homogeneous state based on the premise of one state, one nation. Citizenship in the Turkish Republic was described in Article 88 of Teşkilat-1 Esasiye Kanunu, 1924, meaning that without regard for their religious or ethnic origins, people living in Turkey were to be considered Turks regarding citizenship. Legal regulation, dated 23 May 1928, and numbered 1312, the Türk Vatandaşlığ Kanunu (Turkish Citizenship Law), was also descent based, but territorial understanding is exercised as complementary. The law in use today, dated 11 February 1964 and numbered 403 , is also based on descent, and territorial understanding is exercised as complementary in order to avoid statelessness among the foreigners in the country. ${ }^{29}$

The process of 'citizenization' ${ }^{30}$ and the conceptualization of citizenship in the early Republican period, or the Single Party period, is the most significant in providing background information for understanding the 
current debates on citizenship in Turkey. During that era, the creation of a new Turk or Turkish citizen who had to be, first of all, 'civilized' and 'patriotic' ${ }^{31}$ was the most significant civilizing mission of the Kemalist reformist elite. The Kemalist attempt at transforming subjects into citizens came into being with the rising concern of the political authority for describing who were Turks and who were not, or who the Turks were going to be. ${ }^{32}$ In that ruling, the modernizing elite tried to establish a strong link between citizenship and nationality or national identity. This was regarded in most cases as inevitable in the exercise of citizenship, and, according to their cultural objectives, in defining the profiles of civilized and patriotic citizens of the Republic. It is in this respect that they appeared to take into consideration the idea that creating a shared sense of national culture and identity was a fundamental precondition for forming and strengthening citizenship. That was the main task of the Kemalist nation-building project that required, in its defining of the national and cultural identity of citizens, the total elimination of Ottoman and Islamic heritage, which was considered responsible for the backwardness of the state and society. By striving to eliminate the hegemony of traditional institutions and values over the state structure and society, the Republican elite aimed at building a 'completely secular state' ${ }^{33}$ and a secular socio-cultural structure. That is why the Turkish reform movement stimulated by the nationalist ideology of the Kemalist modernizing state was a sort of cultural revolution or, in the words of Mardin, a 'revolution of values'.$^{34}$ Thanks to its preexistence as a strong, centralized state $^{35}$ that helped to facilitate the process of cultural and linguistic integration, the Republican state projected a particular form of a vision of socio-cultural life, a good life which each Turkish citizen should adopt. This new life would represent a common good and national interest, ${ }^{36}$ but not a particular and individualistic one that was dangerous for national unity.

In forging a new identity, the Turkish state used its powers and agencies to accomplish its social and cultural engineering. It strove to eliminate all previously designated symbols, attitudes and manners, replacing them with its own new myths and symbols. Atatürk defined the 'new' Turk thus: 'We must be civilized men from every point of view; our ideas, our reasoning will be civilized from head to toe. ${ }^{37}$ For him, the nation to which new Turks belonged was composed of citizens tied together by a common language, culture and collective consciousness and ideals, being a political and social entity. ${ }^{38}$ This definition contains no reference to religion - Islam - or tradition. In short, the Kemalists sought to establish a common cultural content, in large measure newly formulated and of course secular, to be used in forging the new Turkish citizens' identity, and for manifesting their position as members of both the state and the organic whole (the nation). 
The conceptualization of citizenship, as it was argued, came hand in hand with constructing a unique, unchangeable and historic Turkish identity that would be made possible only by newly fabricating and imposing a new monolithic culture, while ignoring ethnic and sub-cultural identities. That led to the designation of traditional/Islamic and local cultural symbols to the periphery of the public sphere, and even to the dictation and regulation of everyday life of the new Turks. The Republican civilizing elite, therefore, tried its best to 'penetrate into the life style, manners, behavior and daily customs of the people, and to change the self-conception of Turks' ${ }^{39}$ Each Turkish citizen, equipped with well-defined modes of behaviour, had to be faithful to the his/her own state which, as a representative of collective personality of the nation and citizens, preached the advantages and goodness of being a Turk, a Turkish citizen. In other words, the Republican concept of citizenship was perceived not only as equipping its citizens with the rights and responsibilities of the public sphere, but as forming a totally new man by preaching even the rearrangement of private life, or the very life-style of the people.

While people with different ethnic and cultural origins were to be called Turks, the notion of citizenship was not defined simply in ethnic terms. That is, Turkish nationality was not regarded as the product of biology or blood ties. The new and artificially constructed or 'manufactured' Turkish culture was, therefore, open to non-Turkish Muslim groups, who were accepted as members of the nation and state so long as they were willing to integrate or assimilate culturally and linguistically into Turkish culture. This is the logic of cultural assimilation, not ethnic or racist. The migration of Muslim groups (Bosnians, Albanians, Macedonians) from both the Balkans and the Caucasus was accepted, and those groups were easily naturalized; however, the migrations of the Gagavuz Turks, a small Turkish group with a Christian origin, were hardly accepted. ${ }^{40}$ In a similar way, non-Muslim groups (Greeks, Armenians and Jews) were called Turk only in respect of citizenship but not of nationality; in terms of defining nationality they were seen as outsiders whether or not of Turkish origin, for they were not Muslim. ${ }^{41}$ This shows that in determining the nature of Turkish nationality, in an implicit manner, religion appeared as a significant element together with ethnicity.

Herein lies the paradox of the official definition of Turkish identity and citizenship. While seeming to reject their Ottoman and Islamic heritage, the new regime (Republic) still continued to respect the common historical heritage with those non-Turkish groups mentioned above. Those groups were placed within the Muslim millet in the Ottoman Empire, and, it might be argued, there is a reflection of that millet system in the Turkish Republic in its recognition of the groups that previously were parts of the Muslim 
millet as Turks. In a similar way, the non-Muslim groups remaining in Turkey were regarded as Turkish citizens as a continuation of their community status in the Ottoman Empire. But there were debates on the status of the non-Muslim communities and the problem of their citizenship during the 1920s. The debate was around equality and the assimilation of the non-Muslim population. ${ }^{42}$ On the other hand, it was exclusionary in the sense that the outsiders with non-Muslim origins were hardly accepted as citizens.

Consequently, until the 1950s, the concept of (national) citizenship that was closely bound up with the Kemalist secular notion of Turkishness was culturally, as well as politically, formulated on the basis of homogeneous, generalized and unique secular national culture. It was in this process that the construction of political and social citizenship was realized from above or, in the words of Bryan Turner, 'citizenship rights from above'. ${ }^{43}$

With the transition to a multi-party system the actual defining of the notion and content of the 'official' definition of Turkish identity became a chief objective of the political debate. As a result of such debate certain policies of the state were influenced, and to some extent began to be slowly transformed. The Democrats who put a strong emphasis on Islam and traditional, local values ${ }^{4}$ propagated a peculiar understanding of Turkish nationalism that was more or less coupled with Islam, but that was refuted, at least in terms of their discourses, by the Kemalists in determining the boundaries and nature of the 'enlightened', 'civilized' and 'patriotic' citizen. In spite of these attempts and their later implications, until 1980, religion - Islam - did not exist as one of the officially determined, constitutive elements which were the defining features of Turkish citizens. However, with the social, political and economic changes, religion began to gain importance sociologically speaking, and consequently its impact on politics has been increasing since 1950. Following the 1960 military intervention, the 1961 constitution attempted to provide a venue wherein some civil/societal elements might express themselves. Although, in this sense, it seemed to extend the scope of citizenship, the participation of citizens was actually gained primarily by subscribing to the obligations of the state such as military service, voting and the paying of taxes. ${ }^{45}$ It was seen as significant only in its relation to the ballot box.

The third period in the process of citizenization in Turkey started with the 1980 military intervention and continued in its aftermath. The 1982 constitution might be regarded as a brilliant perversion of the original Kemalist discourse in the sense that it placed more emphasis on 'Turkish historical and moral values'; ${ }^{\prime 4}$ and so Islam was recognized by the state elite with regard to its importance in, at least, maintaining Turkish identity and unity, and as a crucial antidote to communism and other factional and 
divisive movements. In addition, it was used to address the failure of the Kemalist progressive ideals to 'propagate social ethics' and to provide common cultural feelings and values that were 'equivalent for the widely used Islamic idiom' ${ }^{47}$ This was, one may argue, one result of the process of the domestication of the Kemalist modernizing state. ${ }^{48}$ In the last two decades, the assessment of citizenship has been based on not much more than limited political participation (such as voting) and some other duties to the state, from which citizens' rights have been excluded. In spite of these features of the status of citizenship in Turkey, one may not ignore the fact that, in parallel with the development of some civil societal elements facilitated by the changes in the socio-economic structure, we are witnessing a continuously rising debate on citizenship.

The notion of citizenship in Turkey was conceptualized in large measure in terms of a monolithic, unique culture and identity that was the most fundamental product of the process of nation-building; in other words, in a sense, it implies the sense of belonging directly to a (national) community based on loyalty to the state. From the beginning, the formation of citizenship has been realized by emphasizing the significance of manufactured symbols. Notably, during the single party period especially, there were attempts by the regime to prescribe precisely how citizens should speak, dress, behave in public and (even) in private life, and so on. This is why citizenship in Turkey is a cultural status more than a social or political one. This sort of conceptualized citizenship has been challenged by two main trends: first, increasing international migration since 1960, and second, the new increasingly vocal and powerful religious, ethnic and sectarian movements, especially since the 1980s, namely the Kurdish, Islamic and Alevi movements. These movements have played a crucial role in expanding the claims to rights and entitlements to new areas, and in the light of that expansion and diversity of claims, they have posed questions of membership at the cultural, political and social level. The discussion of 'constitutional citizenship' and the implementation of 'dual citizenship' are the result of the controversy over the official citizenship concept that is closely bound with the 'idealized' Kemalist discourse.

As already stressed, there have been two separate social issues that contributed to the debate on the citizenship concept in Turkey since the early 1980s. The first one is associated with international migration and the citizenship position of Turkish emigrants living abroad. The other is related to the citizenship rights of some competing politico-cultural groups such as Kurds, Islamists, and Alevis. While the former has been dealt with in terms of the concept of 'dual citizenship', the latter has brought into focus the 
notion of 'constitutional citizenship'. It is obvious that these two concepts are very different from each other. Nevertheless, common ground exists in that both groups challenge and attempt to redefine the existing concept of citizenship, in order to create more responsive policies that will address their needs more specifically.

The first major challenge to the established notion of citizenship in Turkey was a consequence of international migration. Since the early $1960 \mathrm{~s}$, millions of Turkish citizens in search of work and a better life, and sometimes of political freedom, have left their homes and been admitted as legal residents of Western countries ${ }^{49}$ Many Turkish immigrants have lived in these states for several decades, paid taxes and been affected by political decisions, but they never gained full political rights, since they do not, or cannot, become citizens of the country in which they now live. In fact, before 1981, it was extremely rare to see Turkish emigrants anywhere in the world who had gained citizenship in their host country. Even if it had been the case, it was not possible for Turkish emigrants to assume citizenship status of another country without surrendering their original Turkish citizenship. In short, before 1981 Turkish citizens could not hold multiple (dual) citizenship. In April 1981 Turkish regulations were changed, allowing dual citizenship for the first time. ${ }^{50}$ The effect of this has now become apparent in the numbers of Turkish emigrants gaining citizenship status in the countries where they now reside. For instance, official statistics indicate that there were 126,000 Turkish citizens granted German citizenship in 1996, and by 1998 another 125,000 Turks were expected to became naturalized, bringing the total number of naturalized Turkish citizens in Germany to a quarter million..$^{51}$

It is obvious that, as often happens in most migrant-sending states, Turkey today prefers the blood principle of citizenship. Based on national practical interests, the country wishes to keep close contacts with its citizens abroad, and therefore tends to encourage emigrants to retain their citizenship and transfer it to their children. Of course, concerning the naturalization policies and practices in the migrant-receiving countries, no one can expect that the Turkish state would have any sympathy towards the process in which several hundred thousands of its citizens abroad will be definitely lost. Acknowledging the reality of the permanent presence of its emigrants abroad, and considering the ongoing process of access to citizenship rights in the receiving states, the Turkish state today tends to stress the importance of legal regulations which permit the emigrants to qualify for naturalization without giving up their original citizenship. ${ }^{52}$ Accordingly, from the viewpoint of the state in Turkey, dual citizenship is increasingly seen as an important and practical tool for the integration process of its emigrants in the receiving societies..$^{53}$ 
It seems that dual citizenship provides an opportunity for the Turkish state to overcome several negative consequences of the permanent settlement of its citizens abroad, while at the same time offering some practical solutions to the naturalization difficulties experienced by the migrant-receiving states and emigrants themselves. Since the renunciation of native citizenship is often considered as an enormous psychological and practical barrier to naturalization, it is widely shown that acceptance of dual nationality by the receiving and sending states will increase the inclination of immigrants to naturalize. ${ }^{54}$ Although a basic consensus is achieved regarding the main advantage of dual citizenship, which is to facilitate an easy and quick solution to the anomalous status of immigrants in the migratory process, the inconveniences of dual citizenship have received much more attention than have the positive aspects. For instance, it is argued that dual citizenship will create some complicated situations which cannot be squared with egalitarian democratic norms, such as dual military obligations, dual loyalties, and dual political rights. However, as is pointed out by many proponents of dual citizenship, it is apparent that these inconveniences can be limited by means of bilateral and international agreements. The content of dual citizenship in itself reveals that the process of acquiring the citizenship of another country without giving up the original citizenship involves consequences for governments of both the sending and receiving states as well as for the international migrants. For instance, emphasizing the idea that "everyone should be a citizen of one country and no one should be a citizen of more than one', ${ }^{55}$ many Turkish emigrants living abroad have worried about the application and consequences of dual citizenship. From this perspective, and closely related to the debates concerning citizenship in Turkey, are the emigrants' perceptions and attitudes concerning their own position in the processes of access to citizenship and citizenship rights. What it means to Turkish emigrants to take out citizenship in a host country, why some of them change their membership status while others do not change: these are the questions that require some solid answers.

Some research findings ${ }^{56}$ give us an opportunity to comment on the question of what kinds of meanings, costs and benefits are involved in Turkish emigrants' naturalization decisions. These findings show that when the emigrants were asked why they had become citizens of the receiving states or intended to do so, mostly pragmatic considerations were given as important factors affecting their decisions. For instance, apart from only a few who mentioned the advantages of travelling with the passport of the receiving state, many said that becoming a citizen in receiving states gave them a chance to live both in Turkey and in host countries without having visa and residence permit problems. Having citizenship rights and the right 
to seek permanent positions in public and government services, many emigrants believed that job opportunities would be more abundant not only for themselves but, also most important, for their children. For some, the reasons for becoming a citizen covered some normative and moral motivations together with pragmatic considerations. For instance, they felt that it was a proper step which should be taken after their decision to become permanent residents in the host countries, or they indicated that they would be able to use various rights of citizenship, such as voting, in the country where they live. Meanwhile, emigrants often pointed out that the legal change in Turkey in 1981, allowing dual citizenship for the first time, was a stimulus for their decision.

While those who had become citizens of the receiving states or were intending to do so often emphasized that pragmatic considerations played an important role in their decisions, a large proportion of those who indicated that they did not have any intention of becoming citizens in these receiving states, also gave pragmatic reasons to explain their attitudes. Some believed that they would not get any benefit from naturalization in the host countries; others felt that they might lose some of their rights in Turkey, such as owning property there. ${ }^{57}$ In this context, some complained that dual citizenship regulations in Turkey were unclear and mentioned the rumour about confiscation of properties in the homeland by the Turkish government if they took another citizenship. Some of the emigrants said that they were not willing to become citizens, because they intended to go back home to Turkey for good. For others, the main reason for refusing the rights of citizenship was based on a basic psychological and moral consideration: they said that becoming citizens in these countries was inappropriate because they considered themselves Turkish rather than German, Australian or Swedish.

While Turkey was losing its comfortable certainties regarding the citizenship institution, owing mainly to its participation in the world-wide emigration system, another force made its way to the agenda of the citizenship debate: the persistence of ethnic and religious identities and their struggle for recognition as distinct groups; to be more specific, it was the identity crisis of the Kurds, Islamist and Alevis. It is within this context that the issue of constitutional citizenship began to occupy a place in the various spheres of the Turkish public, government and state. The main idea behind the concept of constitutional citizenship is the fabrication and promotion of a new socio-political identity for everyone in the country, and that identity's relation to citizenship. For instance, after becoming president in 1994, Süleyman Demirel announced the idea of constitutional citizenship several times, ${ }^{58}$ that is the creation of a new 'super identity' for all the members of society, which appears increasingly fragmented into various identity groups 
who are issuing political demands based on their identities. Similarly, Prime Minister Tansu Çiller in December 1994 contributed to the debate with the statement of "what a happiness to the one who says I am a citizen of Turkey', which was actually a converted version of the famous statement of Mustafa Kemal Atatürk, 'what a happiness to the one who says I am a Turk' ${ }^{59}$ It is interesting that the issue of constitutional citizenship has been a kind of item on the official agenda which suddenly appears and then again suddenly disappears. Meanwhile, however, the public ${ }^{60}$ and academicians ${ }^{61}$ show considerable interest in the issue.

The premises of the debate within the context of constitutional citizenship impart criticism toward the legacy of the construction of citizenship in early modern Turkey. ${ }^{62}$ As elaborated in some detail above, in the early period of the Turkish Republic the core argument was to create a new nation, and consequently a new form of membership to this nation, which was meant to be modern, civilized, non-religious and egalitarian with regard to the hitherto hierarchical social structure that were divided across lines of religious, ethnic and national memberships. The ideas of Westernization, nationalism and secularism were considered crucial ideological and practical tools for accomplishing the sense of unity and cultural consensus that is regarded as essential in forming a new citizenship concept in the multicultural population inherited from the Ottoman past. However, it was paradoxical to construct a citizenship concept by accommodating the idea of nationalism based on Turkishness, and at the same time securing the loyalty of non-Turkish populations in the country. Even if we were reminded that the notion of Turkishness was often used with the statement of 'anyone who is bound to the Turkish state by citizenship is Turk', it was extremely difficult to deal with a national type of citizenship in a multiethnic, multinational and multireligious environment. It was also paradoxical to treat religion as glue for a cohesive nation and a bridge between society and state on the one hand and to promote secularism in the country on the other. One of the main consequences of these paradoxical elements since the establishment of the Republic is that the country has been Turkified, and some sectors of the society Islamicized. As another consequence, the recent decades have witnessed identity revivals of the Kurds, Islamists, and Alevis.

Although the most frequently declared aims of the Kurdish movement range from cultural and political rights to federalism and separate statehood, the basic problem seems to be Turkey's failure to recognize Kurds as a distinct ethnic group. ${ }^{63}$ For the Islamists, the main problem has been the exclusion of the Islamic ethos from public discourse and the inclusion of an alien secular nationalism into the larger society. ${ }^{64}$ The Alevi community demands accommodation of their religious identity within mainstream 
institutions such as the Directorate of Religious Affairs, and they wish to establish their own religious institutions. The common point of these demands is a search for a socio-political setting free from alienation and anonymity where these distinct identities can enjoy their social, cultural and political rights. What is implied is that the anomalous picture of the membership status of these distinct identities in Turkey contradicts the very abstract assumption, which is basic to democracy, that people who have their legal residence on the territory of the state are also its members and therefore shall meet all obligations and enjoy full civil, political and social rights in this state. In short, the current positions of Kurds, Islamists, and Alevis create a context in which a new citizenship based on constitutional rights rather than on nationality emerges as a political imperative from the basic principles of democratic citizenship.

Almost every state (country) in the world has its own citizens with various identities. For the most part these are defined in ethnic terms, or in terms of clear identifiable or socially defined attributes. Indeed, the notion of constitutional citizenship comes into the picture at this point. The dynamics and characteristics of the recent constitutional citizenship debate in Turkey are complex and varied. Although for each different actor involved in this debate, its meaning, scope and practice have unique aspects of their own, there is a framework common to the whole debate. To summarize, one can show four basic points which shape this framework. The first is that the struggle of the ethnic and religious identities for recognition as distinct groups has had a very significant impact on the notion of nation-state in Turkey. Second, there is a need to recognize the reality and implications of that identity-based diversity. Third, there is a greater awareness about the need for a series of policy initiatives, which will help the state better to manage the consequences of identity-based diversity in the interests of the state, citizens, and society as a whole. Fourth, there is recognition of the importance of the citizenship institution in solving the identity-based conflicts.

The identity-based conflicts in Turkey have been haunting the political rationality of the Turkish state. It is within this context that the state and public in the country seem to be attracted by the notion of constitutional citizenship as representing something more than a formal legal status of membership. Proponents of constitutional citizenship want to show that this type of citizenship has continuing relevance in securing the loyalty of distinct identity groups in the country who are open to the growing 'divisive' sentiments in society. Opponents of constitutional citizenship, on the other hand, seeing it as a danger to the nation, argue that recognition of ethnic and religious identities will not bring a sense of unity to the nation, and claim that contrary to what is expected, they will always have certain 
serious difficulties in meeting the basic measure of becoming a member of the nation, which is to be bound by a sense of solidarity, a common culture and a national consciousness.

If it is true that 'the development of the concept of membership in a national polity went hand in hand with the nation-states in the West', ${ }^{65}$ then the situation in Turkey today, as has been the case in many other countries, would tell us that there has been a major transformation in recent decades: as pointed out by Silverman, ${ }^{66}$ 'the link between the nation and the state has become visibly dislocated and the gap is likely to grow even more... the dislocation of these elements today, the breakdown in blood and soil definitions of community and the reformulation of the notion of citizenship are all factors in the contemporary crisis of the nation-state'. Although one can acknowledge the difficulties in coping with the diversity of already established policies and the practice and outlook with regard to citizenship issues in various nation-states, the concept of constitutional citizenship seems to be a practical solution. If constitutional citizenship is defined as a formal legal status of the membership of a state, and if this definition implies loyalty to state rather than nation, it will be possible, if not easy, to see that in a country like Turkey where identity-based conflicts endanger the sense of unity, citizenship rights based on constitutional arrangements are important for both symbolic and practical reasons; however, its practical significance is much more important than its symbolic significance.

The Kemalist Revolution began carefully to construct the modern concept of citizenship in Turkey 75 years ago, and there were not many occasions in which the new concept of citizenship was challenged. However, there have been two issues since the early 1980s that have made it a major topic of debate: emigration of Turkish citizens, and as one of its consequences, dual citizenship; and revival of various ethnic and religious identities and their association with the concept of constitutional citizenship. The common denominator of these issues is that they are directly related to the concept of citizenship which is an essential basis in defining the rights, obligations, and identities of individuals in modern societies. It is in these issues, we believe, that we faced the great problems and challenges which confronted Turkey in the 1980s and 1990s. These problems have occurred as previously excluded peripheral identities began to question the fabricated and imposed monolithic citizenship identity which was the product of the early Republican project of social engineering. Briefly, the formal conventional framework of citizenship today can neither accommodate the past 75 years of socio-political change nor articulate the new model of pluralism.

The principal conclusion drawn from this study is that although the pace 
in the recognition process for some new citizenship arrangements in Turkey was quite slow, the Turkish state has eventually become receptive to the case of its emigrants by facilitating them with dual citizenship; but while the state has been dealing with the identity-based conflicts in the country it has had considerable adaptation difficulties and has been confused by the notion of constitutional citizenship. This is of course, something we expect. Some critics have suggested that dual citizenship will create dual loyalties and rights that will encourage emigrants to use their new citizenship rights and benefits, and to ignore their implicit responsibilities to their sending state. However, it is thought that, overall, the acceptance of dual citizenship does not seriously harm these states. On the other hand, however, the notion of constitutional citizenship, which recognizes the multicultural diversity of society, is often seen as a divisive socio-political project for the identity and integrity of the Turkish state. This worry is understandable when the real picture of sociopolitical climate in Turkey is taken into consideration: for instance, Kurdish ethnic nationalism often threatens the unity of the country and creates a potential for violence and war; and religious revivalism makes the situation potentially even more explosive.

However, it seems reasonable to conclude that if citizenship is considered important mostly as a matter of functionalism rather than that of normativism, the task of formulating a new concept of citizenship is not an impossible one. As argued in this study, when access to citizenship rights in an immigration context is considered mainly as a matter of pragmatic choice rather than normative and moral commitment, the notion of dual citizenship becomes a desirable and rational choice for the involved actors. Similarly, if functionalism directs the actors of the politics of citizenship, we believe constitutional citizenship or any other similar formulation would offer promising solutions to the dilemma of pluralism.

We think that Turkey will be more stable and more prosperous only on the condition that it produces new ideas and formulates satisfying answers to the question of 'knowing how to deal with diversity'. Indeed, dual citizenship might be considered as a way of coping with diversity, so that emigrants' identities, demands and practical needs may be satisfied, at least in part, within the framework of a flexible citizenship arrangement. Similarly, within the concept of constitutional citizenship, a new and more complex formula starts imposing itself, the basis of which would combine unity and diversity in a pragmatic way, even if doing so is not easy. In short, what is needed is rethinking of the politics of citizenship. 


\section{NOTES}

1. A. Afet Inan, Medeni Bilgiler ve M. Kemal Atatürk'ün El Yazllan [Civic Information and the Manuscripts of Atatürk] (Ankara, 1988, 2nd. edition).

2. Füsun Üstel, 'Cumhuriyet'ten Bu Yana Yurttaş Profili' [Profile of the Citizen since the Republic], Yeni Yüzyll, 24 April 1995.

3. See Will Kymlicka and Wayne Norman, 'Return of the Citizen: A Survey of Recent Work on Citizenship Theory', Ethics 104 (Jan. 1994), pp.352-81; Bryan Tumer, 'Contemporary Problems in the Theory of Citizenship, in B. Turner (ed.), Citizenship and Social Theory (London, 1993), p.1.

4. Turner, 'Contemporary Problems in the Theory of Citizenship', p.5.

5. Tomas Hammar, 'State, Nation and Dual Citizenship', in William Rogers Brubaker (ed.), Immigration and the Politics of Citizenship in Europe and North America (Lanham, New York, London: The German Marshall Fund of the US, University Press of America Inc., 1989), pp.81-96.

6. Brubaker, 'Immigration, Citizenship, and the Nation-State in France and Germany: A Comparative Historical Analysis', International Sociology, Vol.5, No.4 (1990), pp.380-1. According to this model, membership should be egalitarian, that is, there should be a status of full membership and no other. Secondly, it should be sacred, that is, citizens should make sacrifices or sacred acts for the state. Thirdly, membership should be nation-based, that is, the political community should overlap with the cultural community of shared language and character, which is acquired either by birth or through assimilation. Fourthly, membership should be democratic, that is, members should participate in the ruling process. Fifthly, membership should be unique; people should belong to only one state. Finally, membership should be socially consequential, that is, it should be expressed in a community of wellbeing.

7. William Rogers Brubaker, 'Introduction' in Brubaker (ed.), Immigration and the Politics of Citizenship in Europe and North America, pp.1-27; Citizenship and Nationhood in France and Germany (Cambridge, MA, 1992).

8. Shu-Yun Ma, 'Nationalism: State Building or State Destroying?', The Political Science Journal, Vol.29, No.3 (1992), p.294.

9. David Miller, 'Book Review of Dimensions of Radical Democracy: Pluralism, Citizenship, Community by Chantal Mouffe', American Political Science Review, Vol.87, No.4 (1993), p.1003.

10. T. H. Marshall, Class, Citizenship and Social Development (Garden City, NY, 1965).

11. See Kymlicka and Norman, 'Return of the Citizen: A Survey of Recent Work on Citizenship Theory'.

12. Anne Phillips, Democracy and Difference (Oxford, 1993), p.2.

13. Fuat Keyman, 'On the Relation Between Global Modernity and Nationalism: The Crisis of Hegemony and the Rise of (Islamic) Identity in Turkey', New Perspectives on Turkey, Vol.13 (Fall 1995), p.94.

14. Will Kymlicka, Multicultural Citizenship: a Liberal Theory of Minority Rights (Oxford, 1995).

15. See Kymlicka and Norman, 'Return of the Citizen: A Survey of Recent Work on Citizenship Theory', pp.352-81.

16. Jürgen Habermas, 'Citizenship and National Identity' (1990), in J. Habermas (ed.) Between Facts and Norms (Cambridge, MA, 1996).

17. Tomas Hammar, 'Citizenship: Membership of a Nation and of a State', International Migration, Vol.24, No.4 (1986), pp.735-46; Democracy and the Nation-State (Aldershot, 1990), pp.191-219; Mark J. Miller, 'Dual Citizenship: A European Norm?', International Migration Review, Vol.23, No.4 (1989), pp.945-50.

18. Tbid.

19. Robin West, 'Toward a First Amendment Jurisprudence of Respect: A Comment on George Fletcher's Constitutional Identity', in Michel Rosenfeld (ed.), Constitutionalism, Identity, Difference and Legitimacy (Durham, NC, 1994).

20. For a general discussion on the national and supra-national identity question in the European 
Union, see John Rex, 'National Identity in the Democratic Multi-Cultural State', Sociological Research Online, Vol.1, No.2 (1996); for a specific discussion on the constitutional citizenship in the European Union context, see Habermas, 'Citizenship and National Identity'.

21. Jürgen Habermas, 'Struggles for Recognition in the Democratic Constitutional State', in Amy Gutmann (ed.), Multiculturalism: Examining the Politics of Recognition (Princeton, 1994), p.107.

22. Habermas, 'Citizenship and National Identity', p.496.

23. Ibid.

24. Kymlicka and Norman, 'Return of the Citizen: A Survey of Recent Work on Citizenship Theory', p.373.

25. Halil Inalc1k, 'The Nature of Traditional Society: Turkey', in Robert E. Ward and Dankwart A. Rustow (eds.), Political Modernization in Japan and Turkey (Princeton, 1964), p.56; Ali Kazancigil, 'The Ottoman Turkish State and Kemalizm', in A. Kazancigil and E. Özbudun (eds.), Atatürk: Founder of a Modern State (London, 1981), p.38; and Serif Mardin, 'Religion and Secularism in Turkey', in ibid., p.196.

26. For further details on the 1876 Constitution, see Şeref Gözübüyük and Suna Kili, Türk Anayasa Metinleri [Turkish Constitutional Texts] (Ankara, 1957), pp.21-55.

27. For the extended analysis of the historical development of legal status of citizens in Turkey, see Ergin Nomer, Vatandaşlik Hukuku [Citizenship Law] (Istanbul, 1993, 9th ed.).

28. Metin Heper, 'The State, Religion and Pluralism: The Turkish Case in Comparative Perspective', British Journal of Middle East Studies, 13 (1991).

29. Ergin Nomer, Vatandaşltk Hukuku [Citizenship Law].

30. Robert Nisbet, The Making of Modern Society (Great Britain, 1986), p.131.

31. Füsun Üstel, 'Cumhuriyet'ten Bu Yana Yurttaş Profili' [Profile of the Citizen since the Republic].

32. Identity', Middle Eastern Studies, Vol.32, No.2 (1996), p.177.

33. Metin Heper, 'The State, Religion and Pluralism: The Turkish Case in Comparative Perspective', p.47.

34. Serif Mardin, 'Ideology and Religion in the Turkish Transformation', International Journal of Middle Eastern Studies, Vol.2 (1971), p.209.

35. For further details and discussion on the strong state tradition in Turkey, see Metin Heper, State Tradition in Turkey (Walkington, 1985).

36. For a discussion and the views of Mahmut Esat Bozkurt (Minister of Justice in the İnönü government in the late 1920s) on the relationship between common good and life-style, see Mustafa Baydar, Atatürk ve Devrimlerimiz [Atatürk and Our Reforms] (Istanbul, 1973), pp.208-10.

37. Cited in Yılmaz Altuğ, 'Atatürk and the Building of a Modern State', Turkish Review Quarterly Digest, Vol.5, No.12 (1991), p.34.

38. For Atatürk's views and explanations on nation, culture and citizenship, see Afet Inan, Medeni Bilgiler ve Mustafa Kemal Atatürk'ïn El Yaztlart [Civil Information and the Manuscripts of Atatürk].

39. Nilüfer Göle, 'Authoritarian Secularism and Islamist Politics: The Case of Turkey', in Richard Norton (ed.) Civil Society in the Middle East (Leiden, 1995), p.21.

40. Selçuk Akşin Somel, 'Osmanlı'dan Cumhuriyet'e Türk Kimligì' [Turkish Identity from the Ottoman to the Republic], in Nuri Bilgin (ed.), Cumhuriyet, Demokrasi ve Kimlik [Republic, Democracy and Identity] (Istanbul, 1997), p.81.

41. 'One may', writes B. Lewis, 'speak of Christian Arabs, but a Christian Turk is an absurdity and a contradiction in terms. Even after thirty years of the secular Republic, a non-Muslim in Turkey may be called a Turkish citizen, but never a Turk.' Bernard Lewis, 'Turkey: Westernisation', in G. E. von Grunebaum (ed.), Unity and Variety in Muslim Civilization (Chicago, 1955), p.326.

42. There were, for example, volunteers for integration in the Jewish community; some of them regarded Jews as Turks from the Judaic religion while Tekinalp, a converted Jew, delineated the testament for Turkification. For the discussion of the status of Jews in Turkey see Avner Levi, Türkiye Cumhuriyeti'nde Yahudiler [Jews in the Republic of Turkey] (Istanbul, 1993). 
43. In this connection, Turner argues, the citizen is seen as 'a mere subject rather than active bearer of effective claims against society via the state'. B.S. Turner, 'Outline of a Theory of Citizenship', in Chantal Mouffe (ed.), Dimensions of Radical Democracy (London, 1992), p.46.

44. Serif Mardin, 'Center-Periphery Relations: A Key to Turkish Politics?', Daedalus, 102 (1973), p.169.

45. Füsun Üstel, 'Yurttaşlık Bilgisi Kitapları ve Yurttaş Profili’ [Schoolbooks on Citizenship and Profile of the Citizen], Yeni Yüzyll, 25 April 1995.

46. Metin Heper, State Tradition in Turkey, p.146.

47. Serif Mardin, 'Islam in Mass Society: Harmony versus Polarization', in Metin Heper and Ahmet Evin (eds.), The Politics in the Third Turkish Republic (Boulder, CO, 1994), pp. $163-4$.

48. Chris Hann describes the process Turkey entered into with the transition to a multi-party system as the domestication of the modernizing state, that is, the state began taking into consideration the pressure and demands from below, and partially rearranging its policies in accordance with these demands: Chris Hann, 'Subverting Strong States: The Dialectics of Social Engineering in Hungary and Turkey', Daedalus, Vol.126, No.2 (1995).

49. For a voluminous annotated bibliography of the studies on Turkish migration to Western European countries see N. Abadan-Unat and N. Kemiksiz, Türk Dış Göçü: 1960-1984 [Turkish External Migration: 1960-1984] (Ankara, 1986). For a recent study of the Turkish emigration to Europe, see also Ahmet İçuygu. Migration from Turkey to Western Europe: Recent Trends and Prospects', paper presented to the Mediterranean Conference on Population, Migration and Development, Palma de Mallorca, 15-17 Oct. 1996.

50. Some articles of the Turkish Citizenship Law, originally dated 22 Feb. 1964 and numbered 403, were changed on 13 Feb. 1981, with the Law No.2383.

51. See Volkan Bozkaya, 'Life Situation, Identity and Integration of Turks in the Federal Republic of Germany', paper presented at the 3rd National Population Conference, Hacettepe University, 2-5 Dec., Ankara; in relation to the effect of the 1981 regulations, which caused an increasing trend in the number of Turkish immigrants taking out citizenship of the receiving states after 1981, see Ahmet Içduygu, 'Citizenship at the Crossroads: Immigration and the Nation-State', in Eleonore Kofman and Gillian Youngs (eds.), Globalisation, Theory and Practice (London, 1996), pp.154-60, and also see Ahmet İçduygu, 'Becoming a New Citizen in an Immigration Country: Turks in Australia and Sweden', International Migration, Vol.34, No.1 (1996), pp.257-74.

52. As an example of the increasing Turkish official interest to the dual citizenship issue, see $\mathrm{K}$. Akın, 'Yurttaşlık Nasıl Korunur' [How to Protect the Citizenship], Yeni Birlik, Vol.11, No.11, 1988 (an interview with the Deputy Director of the Office of Population and Citizenship, Ministry of Interior).

53. For instance, the dual citizenship debate was intensified when in May 1993 five Turkish women and children were killed in an arson attack in Solingen, Germany. After the incident, Turkish officials often argued that Turkey wanted easier naturalization and dual citizenship for the Turkish nationals in Europe, which is seen as a tool to discourage violence towards Turks abroad.

54. See Brubaker, 'Introduction', pp.115-16, and Miller, 'Dual Citizenship: A European Norm?', p.948.

55. See, for instance, for a related debate, Report on Political Participation (Strasbourg, 1991).

56. See Ahmet İçuygu, 'Citizenship at the Crossroads: Immigration and the Nation-State', and Ahmet İçduygu, 'Becoming a New Citizen in an Immigration country: Turks in Australia and Sweden'.

57. New regulations had to be done in June 1995 about the protection of the rights and possessions of Turkish citizens in the case of their citizenship position change. See, Türk Vatandaşlığı Kanununda Değişiklik Yaptlmasına Ilişkin Kanun [Law on the Change in the Turkish Citizenship Law], Law No.4112, Date: 7.6.1995, Official Gazette.

58. See for instance, Ertuğrul Özkök, 'Demirel Anayasal Vatandaşlı̆ga Dönüyor’ [Demirel, Turning to the Constitutional Citizenship], Hürriyet, 3 Dec. 1996.

59. See, G. Zeynep Çetinkaya, 'Ne Mutlu'ya Kimlik Aranıyor' [Identity wanted to what a happiness], Pazar Postast, 7 Jan. 1995. 
60. See, for instance, Ertuğrul Özkök, 'Demirel Anayasal Vatandaşlığa Dönüyor'. See G. Zeynep Çetinkaya, 'Ne Mutlu'ya Kimlik Aranıyor'.

61. See Ahmet İçduygu, ‘Çokkültürlüllük' [Multiculturalism], Türkiye Günlüğüi (March-April 1995); Füsun Üstel, 'Anayasal Vatandaşlık, Hangi Anayasaya Vatandaşlı?' [Constitutional Citizenship, Citizenship to What Constitution?], Radikal, 17 Dec. 1996; Nur Vergin, 'Anayasal Vatandaşlık Ne Demektir?' [What Does Constitutional Citizenship Mean?], Milliyet, 26 Dec. 1996.

62. Although there is no direct reference to the concept of constitutional citizenship, the following two articles provide a historical background in which the debate was intensified: the first one is Ergun Özbudun, 'Milli Mücadele ve Cumhuriyet'in Resmi Belgelerinde Yurttaşlık ve Kimlik Sorunu' [National Struggle and the Problem of Citizenship and Identity in the Official Documents of the Republic], in Nuri Bilgin (ed.), Cumhuriyet, Demokrasi ve Kimlik (Istanbul, 1997), pp.63-70; and the second one is Selçuk Akşin Somel, 'Osmanlı'dan Cumhurıyet'e Türk Kimliği' [Turkish Identity from the Ottoman to the Republic]; Ömer Faruk Gençkaya, 'Revival of the Periphery: Need for Consensus or Threat to National Integrity in Turkey', Journal of Behavioral and Social Sciences, Vol.1 (1997), pp.75-90.

63. See, Nimet Beriker-Atiyas, 'The Kurdish Conflict in Turkey: Issues, Parties and Prospects', Security Dialogue, Vol.28, No.4 (1997), pp.439-52.

64. See, Hakan Yavuz, 'Turkey's Imagined Enemies: Kurds and Islamists', The World Today (April 1996), pp.99-101.

65. Ayşe Kadığlu, 'Citizenship, Immigration and Racism in a Unified Germany with Special reference to the Turkish Guestworkers', Journal of Economics and Administrative Studies, Vol.6, Nos.1-2 (1992), p.200,

66. M. Silverman, Deconstructing the Nation (London, 1992), p.35. 